\title{
INFLUENCE OF SALINITY ON ALIPHATIC AND INDOLE GLUCOSINOLATES IN BROCCOLI (Brassica oleracea var. italica)
}

\author{
SARIKAMIŞ, G. ${ }^{1 *}-$ ÇAKIR, A. ${ }^{2}$ \\ ${ }^{1}$ Ankara University, Faculty of Agriculture, Department of Horticulture, Ankara, Turkey \\ ${ }^{2}$ Bingöl University, Faculty of Agriculture, Department of Horticulture, Bingöl, Turkey \\ *Corresponding author \\ e-mail: Golge.Sarikamis@agri.ankara.edu.tr \\ (Received 27 $7^{\text {th }}$ Feb 2017; accepted $25^{\text {th }}$ May 2017)
}

\begin{abstract}
Broccoli (Brassica oleracea var. italica) synthesizes sulphur containing plant secondary metabolites known as glucosinolates that are often associated with bioactive properties upon hydrolysis. Glucosinolates are part of plant defence system and the glucosinolate content in plants is usually influenced by several factors including the genetic background of plants, developmental stage, environmental factors and soil conditions. The evaluation of factors affecting glucosinolate content in plants is important to obtain plants with improved bioactive properties. The objective of the present study was to determine the effect of $\mathrm{NaCl}(0,40,80,100 \mathrm{mM})$ on aliphatic and indole glucosinolate content of broccoli grown in greenhouse conditions. For this purpose, broccoli seedlings at 5-6 leaf were irrigated with 0 (control), $40 \mathrm{mM}, 80 \mathrm{mM}$ and $100 \mathrm{mM} \mathrm{NaCl}$. Glucosinolates were determined at three different time points $(1,3,6$ days upon treatment). According to the findings, the amount of individual and total aliphatics and indoles were lower at 40,80 and $100 \mathrm{mM} \mathrm{NaCl}$ applications compared to control plants determined at three different time points $(\mathrm{P}<0.001)$ suggesting the break down of glucosinolates due to stress conditions. The findings of the study revealed the glucosinolate profile and content of broccoli seedlings under saline conditions.
\end{abstract}

Keywords: brassica, stress, salinity, secondary metabolites

\section{Introduction}

Plants are exposed to various environmental conditions including climate and soil factors during their growth cycle. Unfavourable conditions such as high or low temperatures, drought, salinity and mineral nutrient deficiency in soil may limit the plant growth and development. Salinity is one of the major abiotic stress factors affecting plant physiology, growth and development (Zhu, 2001). Plants respond to such limiting conditions through the activation of their primary and secondary metabolism in order to overcome stress conditions and survive (Khan et al., 2009; Velasco et al., 2007). Under salinity stress, plants undergo an osmotic adjustment. In addition, in order to maintain the water balance, cells accumulate secondary metabolites. Glucosinolates, ascorbic acid, phenolic compounds and anthocyanin are the major secondary metabolites involved in plant defense against stress conditions (LópezBerenguer et al., 2008).

Glucosinolates are plant secondary metabolites mainly present in the Brassicaceae and known to act as a plant defence system against insect and pathogen attacks (Cole, 1997) as well as environmental stress factors such as salinity (Qasim et al., 2003). Glucosinolates have attracted a great deal of attention delivering antimicrobial (Aires et al. 2009), antioxidant (Nilsson et al., 2006) and anticarcinogenic properties (Ávila et al., 2013). These 
beneficial effects are attributed to isothiocyanates which are the hydrolysis products of glucosinolates (Navarro et al., 2011). Glucoraphanin (4-methylsulphinylbutyl) in broccoli has been of interest as the precursor of sulforaphane 1-isothiocyanato-4methylsulphinylbutane.

Salinity has been shown to influence glucosinolate content in plants. However, the effect is dependent on many factors including the developmental stages of the plant, the tissue and plant part analyzed, the cultivar effect and salinity doses applied. In addition variation exists in terms of aliphatic and indole glucosinolates. Total glucosinolate content in broccoli leaves showed a slight increase after 1 day of saline treatment $(40$ and $80 \mathrm{mM})$, but with no significant differences with regard to the controls. However, at 15 days, the total glucosinolates content was found higher in control leaves than in $40 \mathrm{mM} \mathrm{NaCl}$-treated plants, with a marked increase at $80 \mathrm{mM} \mathrm{NaCl}$ (López-Berenguer et al., 2008). Hassini et al. (2016) reported that salinity $(150 \mathrm{mM})$ did not change glucosinolate content in broccoli.

The amount and pattern of glucosinolates may vary according to the genetic background of individuals as well as various environment and ontogenic factors as reviewed (Sarıkamış, 2009). Similarly, plant tolerance to stress factors may vary accordingly.

The objective of the present study is to assess the influence of salinity on aliphatic and indole glucosinolate content in young broccoli seedlings in order to evaluate the status of these health promoting compounds under stress conditions at earlier developmental stages.

\section{Material and Methods}

\section{Plant Material}

The experiment was conducted at the Department of Horticulture, Faculty of Agriculture, Ankara University. Broccoli (Brassica oleracea var. italica 'Marathon') seeds were sown in plug trays $(5.5 \mathrm{~cm}$ width and $6 \mathrm{~cm}$ depth) containing a mixture of peatmoss (Plantaflor-Humus, Verkaufs-GmBH, Germany) and perlite (1:1). Seedlings at 2-3 leaf stage were transferred to $7 \mathrm{~L}$ containers filled with peat moss:perlit:cocopeat $(1: 1: 1)$ mixture and maintained in the greenhouse. Daily temperature and humidity were recorded from measurements taken every 20 min using dataloggers in greenhouse (Fig. 1). Daily mean temperature were averaged between $21.72-28^{\circ} \mathrm{C}$ and relative humidity between $53.2-63.11 \%$ in the greenhouse during the experiment.

\section{Salinity Treatments}

Broccoli seedlings at 5-6 leaf stage ( 2 weeks after transplanted to the plastic containers) were irrigated with 0 (control), $40 \mathrm{mM}, 80 \mathrm{mM}$ and $100 \mathrm{mM} \mathrm{NaCl}$. The $\mathrm{pH}$ of the growing media measured as 6.5-7.5. Leaf samples were collected at 1, 3, 6 days after $\mathrm{NaCl}$ treatment.

\section{Analysis of Glucosinolates}

The glucosinolates were extracted from two upper young leaves. Leaf samples were freeze-dried prior to the analysis. Extraction of glucosinolates, conversion to desulfoglucosinolates and analysis by HPLC was as described previously by (Sarikamis et al., 2006). Samples were analysed and separated by HPLC-UV (Shimadzu ${ }^{\circledR}$ ) in the HPLC laboratory at Ankara University, Department of Horticulture. A volume of $50 \mu 1$

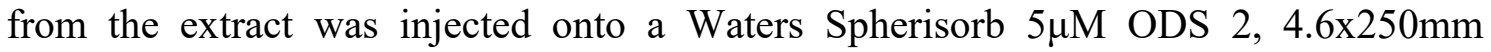
analytical cartridge. Analysis was carried out on a gradient of $99 \%$ water and $1 \%$ 
acetonitrile at a flow rate of $1 \mathrm{ml} / \mathrm{min}$ for $24 \mathrm{~min}$. The detection was carried out at a wavelength of $229 \mathrm{~nm}$. Glucotropaeolin (benzyl glucosinolate) was used as the internal standard for the quantification of the peaks. Glucosinolates were quanified according to internal standards and expressed as $\mu \mathrm{molg}^{-1}$ dry weight (DW). Correction factors were used during quantification for each compound as listed by (Brown et al., 2003)

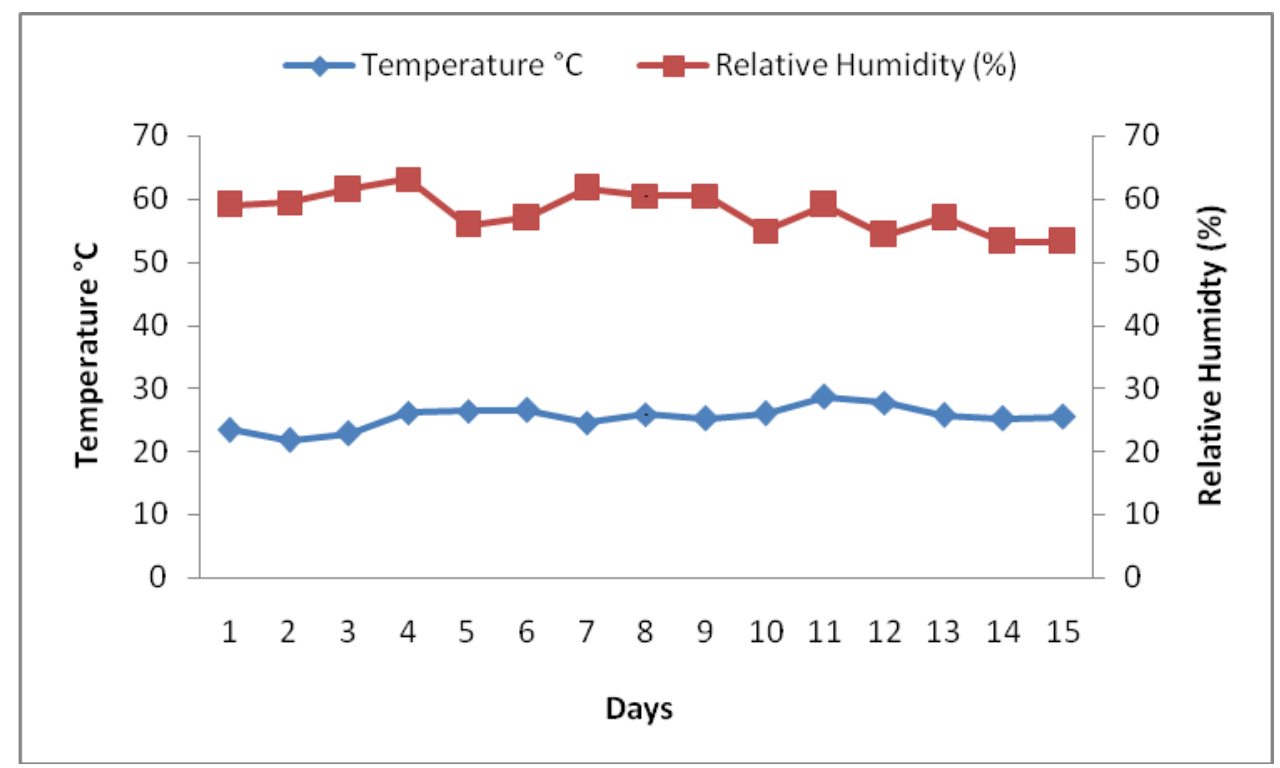

Figure 1. Changes in temperature $\left({ }^{\circ} \mathrm{C}\right)$ and relative humidity $(\%)$ in the greenhouse during the experimental period

\section{Statistical Analysis}

The experiment was conducted according to completely randomized design as three replicates each replicate contained four plants. Experimental data were expressed as the mean \pm standard error of the mean with three replications $(n=3)$. One-way analysis of variance and Duncan's multiple range test was used to determine the significance of differences using SPSS 18.0 (SPSS Inc.,Chicago, IL). Significant differences were evaluated at $\mathrm{P}<0.001$ error level.

\section{Results and Discussion}

The effect of $\mathrm{NaCl}$ treatments $(0,40,80,100 \mathrm{mM})$ on aliphatic and indole glucosinolate content of broccoli seedlings were determined on leaf samples collected at three different time points (1, 3, 6 days upon treatment) in greenhouse conditions. Glucosinolates determined were glucoiberin (3-methylsulphinlypropyl), glucoraphanin (4-methylsulphinylbutyl), glucobrassicin (3-indolylglucobrassicin), 4methoxyglucobrassicin (4-methoxy-3-indolylmethyl), neoglucobrassicin (1-methoxy-3indolylmethyl) and 4-hydroxyglucobrassicin (4-hydroxy-3-indolylmethyl). The predominant glucosinolates were glucobrassicin of the indole group followed by glucoraphanin of the aliphatics (Table 1). 
Table 1. Glucosinolate content of broccoli seedlings at 0,40,80,100m M NaCl applications on 1,3,6 days

\begin{tabular}{|c|c|c|c|c|c|}
\hline Glucosinolates & Time & $0 \mathrm{mM}$ & $40 \mathrm{mM}$ & $80 \mathrm{mM}$ & $100 \mathrm{mM}$ \\
\hline \multirow[t]{3}{*}{ Glucoiberin } & Day 1 & $0.890 \pm 0.118 \mathrm{a}$ & $0.543 \pm 0.127 b$ & $0.467 \pm 0.114 b$ & $0.667 \pm 0.143 b$ \\
\hline & Day 3 & $1.003 \pm 0.173 \mathrm{a}$ & $0.247 \pm 0.154 b$ & $0.82 \pm 0.09 b$ & $0.6825 \pm 0.0962 b$ \\
\hline & Day 6 & $1.270 \pm 0.228 \mathrm{a}$ & $1.060 \pm 0.348 \mathrm{a}$ & $0.387 \pm 0.194 b$ & $0.870 .478 \mathrm{ab}$ \\
\hline \multirow[t]{3}{*}{ Glucoraphanin } & Day 1 & $4.640 \pm 0.386 \mathrm{a}$ & $2.250 \pm 1.22 \mathrm{ab}$ & $1.820 \pm 1.20 \mathrm{~b}$ & $3.817 \pm 0.556 \mathrm{ab}$ \\
\hline & Day 3 & $5.260 \pm 0.460 \mathrm{a}$ & $3.790 \pm 1.34 b$ & $2.060 \pm 0.960 \mathrm{~b}$ & $3.438 \pm 0.895 b$ \\
\hline & Day 6 & $5.687 \pm 0.463 \mathrm{a}$ & $4.730 \pm 2.11 \mathrm{ab}$ & $2.630 \pm 1.13 b$ & $4.540 \pm 2.84 \mathrm{ab}$ \\
\hline \multirow[t]{3}{*}{ Glucobrassicin } & Day 1 & $13.167 \pm 0.524 \mathrm{a}$ & $8.840 \pm 3.57 \mathrm{ab}$ & $6.910 \pm 2 b$ & $11.920 \pm 1.99 \mathrm{a}$ \\
\hline & Day 3 & $15.293 \pm 0.695 \mathrm{a}$ & $4.3367 \pm 0.0865 b$ & $9.83 \pm 5.13 \mathrm{ab}$ & $8.190 \pm 0.817 \mathrm{ab}$ \\
\hline & Day 6 & $15.103 \pm 0.211 \mathrm{a}$ & $9.300 \pm 2.21 \mathrm{ab}$ & $5.28 \pm 1.21 b$ & $11.280 \pm 0.617 \mathrm{ab}$ \\
\hline \multirow[t]{3}{*}{ 4-Methoxyglucobrassicin } & Day 1 & $1.550 \pm 0.407 \mathrm{a}$ & $0.630 \pm 1.092 b$ & $0.417 \pm 0.723 b$ & $0.491 \pm 0.851 \mathrm{~b}$ \\
\hline & Day 3 & $1.570 \pm 0.466 \mathrm{a}$ & $0.8067 \pm 0.0841 b$ & $2.24 \pm 1.37 \mathrm{a}$ & $1.480 \pm 0.225 \mathrm{ab}$ \\
\hline & Day 6 & $1.883 \pm 0.196 \mathrm{ab}$ & $3.05 \pm 1.02 \mathrm{a}$ & $0.853 \pm 0.267 \mathrm{~b}$ & $1.537 \pm 0.748 \mathrm{ab}$ \\
\hline \multirow[t]{3}{*}{ 1- Methoxyglucobrassicin } & Day 1 & $1.593 \pm 0.348 \mathrm{a}$ & $2.61 \pm 1.29 \mathrm{a}$ & $2.373 \pm 0.854 \mathrm{a}$ & $1.510 \pm 1.04 \mathrm{a}$ \\
\hline & Day 3 & $1.307 \pm 0.575 \mathrm{a}$ & $2.810 \pm 0.361 \mathrm{a}$ & $2.780 \pm 4.41 \mathrm{a}$ & $1.950 \pm 0.682 \mathrm{a}$ \\
\hline & Day 6 & $1.350 \pm 0.617 \mathrm{a}$ & $1.50 \pm 4.41 \mathrm{a}$ & $1.92 \pm 1.75 \mathrm{a}$ & $1.570 \pm 2.54 \mathrm{a}$ \\
\hline \multirow[t]{3}{*}{ 4-Hydroxyglucobrassicin } & Day 1 & $0.397 \pm 0.116 \mathrm{a}$ & $0.206 \pm 0.0821 \mathrm{a}$ & $0.176 \pm 0.0623 \mathrm{a}$ & $0.396 \pm 0.0821 \mathrm{a}$ \\
\hline & Day 3 & $0.333 \pm 0.145 \mathrm{a}$ & $0.086 \pm 0.0033 \mathrm{a}$ & $0.280 \pm 0.190 \mathrm{a}$ & $0.267 \pm 0.0377 \mathrm{a}$ \\
\hline & Day 6 & $0.413 \pm 0.139 a$ & $0.416 \pm 0.0769 a$ & $0.500 \pm 0.0987 \mathrm{a}$ & $0.620 \pm 0.0850 \mathrm{a}$ \\
\hline
\end{tabular}


Total aliphatic glucosinolates at day 1 were determined as $5.53 \pm 0.40 \mu \mathrm{molg}^{-1} \mathrm{DW}$, while total indoles were determined as $16.71 \pm 0.71 \mu \mathrm{molg}^{-1} \mathrm{DW}$ in control plants. The amount of total aliphatics and indoles were decreased at 40 and $80 \mathrm{mM} \mathrm{NaCl}$, aliphatics determined as $2.79 \pm 1.20,2.28 \pm 1.14$ and indoles as $12.29 \pm 2.21,9.88 \pm 0.35 \mu \mathrm{molg}^{-1} \mathrm{DW}$ respectively which was later slightly increased to $4.48 \pm 0.96 \mu \mathrm{molg}^{-1} \mathrm{DW}$ in aliphatics and $14.32 \pm 1.29 \mu \mathrm{molg}^{-1}$ DW for indoles at $100 \mathrm{mM}$ but still lower than control plants $(\mathrm{P}<0.001)$ (Fig. 2). On the third day of application, total aliphatic and indoles were decreased significantly at $40,80,100 \mathrm{mM}$ doses $(\mathrm{P}<0.001)$. On the sixth day of application, similar to day 1 , a decrease was observed compared to the control plants at 40, 80mM and at 100mM both in aliphatics and indoles $(\mathrm{P}<0.001)$ (Fig. 2).

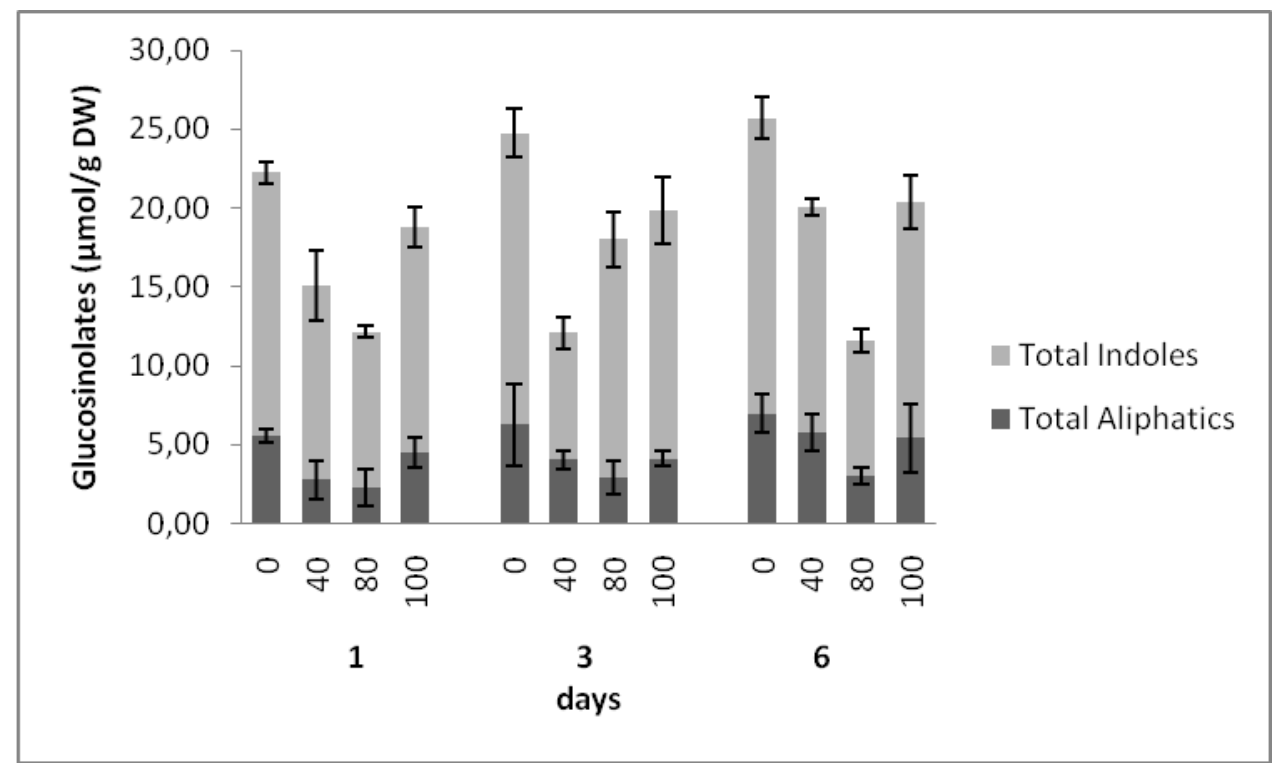

Figure 2. Changes in total and aliphatic glucosinolates at 0 (control), 40, 80, $100 \mathrm{mM} \mathrm{NaCl}$ applications (days 1,3,6)

In terms of individual glucosinolates, glucoraphanin was the predominant aliphatic glucosinolate compared to glucoiberin. Glucoiberin content decreased at 40, 80, $100 \mathrm{mM}$ $\mathrm{NaCl}$ applications at day 1 and 3, and decreased at 80 and $100 \mathrm{mM}$ at day $6(\mathrm{P}<0.001)$. Similarly glucoraphanin content decreased with $\mathrm{NaCl}$ applications $(\mathrm{P}<0.001)$ (Table 1).

Glucobrassicin determined as the predominant indole glucosinolate.Glucobrassicin content decreased at 40,80 NaCl concentratrions. At day 3, the increase was highest at $80 \mathrm{mM} \mathrm{NaCl}(\mathrm{P}<0.001)$. A decreasing trend was observed at 4-methoxyglucobrassicin except day 3 where an increase was observed at $80 \mathrm{mM}$ and day 3 , the highest level was reached at $40 \mathrm{mM} \mathrm{NaCl}$. Slight increase was determined in 1-methoxyglucobrassicin at 40 and $80 \mathrm{mM} \mathrm{NaCl}$ however the increase was not statistically important $(\mathrm{P}>0.001)$. The amount of 4-hydroxyglucobrassicin was lowest among indoles and there was not significant variation among treatments $(\mathrm{P}>0.001)$.

Glucosinolates are a group of secondary metabolites usually associated with health promoting properties (Dinkova-Kostova and Kostov, 2012; Verkerk et al., 2009). In a previous study, glucosinolates were shown to be influenced by salinity stress (Pang et al., 2012) suggesting that under low water potential they could be involved in osmotic adjustment and might be involved in salt tolerance in plants (Lopez Berenguer et al., 2009). 
In the present study, the individual and total aliphatic glucosinolates as well as indoles of the broccoli seedlings were decreased significantly by $\mathrm{NaCl}$ application at 40 and $80 \mathrm{mM} \mathrm{NaCl}$ compared to control plants whereas a slight but insignificant increase was observed at $100 \mathrm{mM} \mathrm{NaCl}$. A few studies report the influence of salinity on the content of glucosinolates in broccoli florets (Lopez Berenguer et al., 2009), radish sprouts (Yuan et al., 2010), broccoli sprouts (Guo et al., 2014) suggesting differential responses to salinity. The content of intact aliphatic and indole glucosinolates in the inflorescences of broccoli cultivars Nubia, Naxos and Parthenon has also revealed differential response to salinity treatments (Dominguez Perles et al., 2011). In another work aimed to improve health promoting glucosinolates in edible sprouts suggested that glucoraphanin content decreased significantly, indole glucosinolates neoglucobrassicin, 4-hydroxyglucobrassicin and glucobrassicin were reported to decrease by 40 and $80 \mathrm{~mm}$ $\mathrm{NaCl}$ and increase by $100 \mathrm{mM} \mathrm{NaCl}$ application in $7 \mathrm{~d}$ old broccoli sprouts germinated under different $\mathrm{NaCl}$ doses (Guo et al., 2013). Different from above mentioned studies, our work aimed to determine the influence of salinity on glucosinolates in broccoli seedlings representing earlier developmental stages.

Although a few studies highlight the different responses of glucosinolates to salt stress, the mechanism behind is still not clear. The differential variation of glucosinolates is related to the strong metabolism alteration, turgor adjusting leading to a high growth reduction (López-Berenguer et al., 2009). On the other hand, exposure to stress may lead to cell membrane damage and the decrease in relative water content (Wang et al., 2013). Therefore, the decreases in glucosinolate content can be attributed to the break down of glucosinolates (hydrolysis) due to cellular damage caused by oxidative stress.

\section{Conclusion}

Broccoli contains sulforaphane that is often associated with health promoting activities including the anticancer properties. The precursor of sulforaphane is glucoraphanin which is an aliphatic glucosinolate and the amount of glucosinolates, glucoraphanin in particular, is important in order to gain health benefits. However, the amount of glucosinolates depend on several factors including the environmental and soil conditions during the growth period, stress factors and the developmental stage of the plant. Therefore in the present study, the effect of saline conditions on glucosinolate content of broccoli were determined in broccoli seedlings at 5-6 leaf stage grown in greenhouse conditions. The findings suggested an overall decrease in aliphatic glucosinolates and glucoraphanin as well as total glucosinolates compared to control plants. The decrease was attributed to the degradation of glucosinolates via the enzyme myrosinase also present in plant cells probably activated upon cellular damage caused by $\mathrm{NaCl}$ applications.

\section{REFERENCES}

[1] Aires, A., Mota, V., Saavedra, M., Rosa, E., Bennett, R. (2009): The antimicrobial effects of glucosinolates and their respective enzymatic hydrolysis products on bacteria isolated from the human intestinal tract.- Journal of Applied Microbiology 106: 2086-2095.

[2] Ávila, F. W., Faquin, V., Yang, Y., Ramos, S. J., Guilherme, L. R. G., Thannhauser, T. W., Li, L. (2013): Assessment of the anticancer compounds Se-methylselenocysteine and 
glucosinolates in Se-biofortified broccoli (Brassica oleracea L. var. italica) sprouts and florets. -Journal of Agricultural and Food Chemistry 61: 6216-6223.

[3] Brown, P. D., Tokuhisa, J. G., Reichelt, M.,Gershenzon, J. (2003): Variation of glucosinolate accumulation among different organs and developmental stages of Arabidopsis thaliana.- Phytochemistry 62: 471-481.

[4] Cole, R. (1997): Comparison of feeding behaviour of two Brassica pests Brevicoryne brassicae and Myzus persicae on wild and cultivated Brassica species. -Entomologia Experimentalis et Applicata 85: 135-143.

[5] Dinkova-Kostova, A. T., Kostov, R. V. (2012): Glucosinolates and isothiocyanates in health and disease.- Trends in Molecular Medicine 18: 337-347.

[6] Dominguez-Perles R., Martinez-Ballesta, M.C., Riquelme, F.. Carvajal, M., Garcia-Viguera, C., Moreno, D.A. (2011): Novel varieties of broccoli for optimal bioactive components under saline stress. -Journal of Science, Food and Agriculture 91(9):1638-47.

[7] Guo, L., Yang, R., Wang, Z., Guo, Q., Gu, Z. (2014): Effect of NaCl stress on healthpromoting compounds and antioxidant activity in the sprouts of three broccoli cultivars.International Journal of Food Science Nutrition 65: 476-81.

[8] Guo, R.F., Yuan, G.F., Wang, Q.M. (2013): Effect of $\mathrm{NaCl}$ treatments on glucosinolate metabolism in broccoli sprouts. -Journal of Zhejiang University Science B 14: 124-131.

[9] Hassini, I., Baenas, N., Moreno, D. A., Carvajal, M., Boughanmi, N., Martinez Ballesta, M.D.C. (2016): Effects of seed priming, salinity and methyl jasmonate treatment on bioactive composition of Brassica oleracea var. capitata (white and red varieties) sprouts.Journal of the Science of Food and Agriculture. doi: 10.1002/jsfa.8037. [Epub ahead of print]

[10] Khan, N., Nazar, R., Anjum, N. (2009): Growth, photosynthesis and antioxidant metabolism in mustard (Brassica juncea L.) cultivars differing in ATP-sulfurylase activity under salinity stress. -Scientia Horticulturae 122: 455-460.

[11] López-Berenguer, C., Martínez-Ballesta, M.C., Moreno, D.A., Carvajal, M., GarciaViguera, C. (2009): Growing hardier crops for better health: salinity tolerance and the nutritional value of broccoli.- Journal of Agriculture and Food Chemistry 57(2):572-578.

[12] López-Berenguer, C., Martínez-Ballesta, M.C., García-Viguera, C., Carvajal, M. (2008): Leaf water balance mediated by aquaporins under salt stress and associated glucosinolate synthesis in broccoli.- Plant Science 174(3):321-328.

[13] Navarro, S. L., Li, F., Lampe, J. W. (2011): Mechanisms of action of isothiocyanates in cancer chemoprevention: an update.- Food and Function 2(10): 579-587.

[14] Nilsson, J., Olsson, K., Engqvist, G., Ekvall, J., Olsson, M., Nyman, M., Akesson, B. (2006): Variation in the content of glucosinolates, hydroxycinnamic acids, carotenoids, total antioxidant capacity and low-molecular-weight carbohydrates in brassica vegetables.- Journal of Science, Food and Agriculture 86(4):528-538.

[15] Pang, Q., Guo, J., Chen, S., Chen, Y., Zhang, L., Fei, M., Jin, S., Li, M., Wang, Y., Yan, $X$. (2012): Effect of salt treatment on the glucosinolate-myrosinase system in Thellungiella salsuginea.- Plant Soil 355(1-2):363-374.

[16] Qasim, M., Ashraf, M., Ashraf, M., Rehman, S.U., Rha, E. (2003): Salt-induced changes in two canola cultivars differing in salt tolerance.- Biologica Plantarum 46(4):629-632.

[17] Sarıkamış, G., Marquez, J., Maccormack, R., Bennett, R.N., Roberts, J., Mithen, R. (2006): High glucosinolate broccoli: a delivery system for sulforaphane.- Molecular Breeding 18(3):219-228.

[18] Sarıkamış, G. (2009): Glucosinolates in crucifers and their potential effects against cancer: Review.- Canadian Journal of Plant Science 89(5):953-959.

[19] Velasco, P., Cartea, M.E., Gonzalez, C., Vilar, M., Ordas, A. (2007): Factors affecting the glucosinolate content of kale (Brassica oleracea acephala group).- Journal of Agricultural and Food Chemistry 55(3):955-62.

[20] Verkerk, R., Schreiner, M., Krumbein, A., Ciska, E., Holst, B., Rowland, I., De Schrijver, R., Hansen, M., Gerhäuser, C., Mithen, R., Dekker, M. (2009): Glucosinolates in 
Brassica vegetables: the influence of the food supply chain on intake, bioavailability and human health.- Molecular Nutrition Food Research 53(S2):219-219.

[21] Wang, Y., Xu, W.J., Yan, X.F. (2013): Glucosinolate content and related gene expression in response to enhanced UV-B radiation in Arabidopsis.- African Journal of Biotechnology 10(34):6481-6491.

[22] Yuan, G., Wang, X., Guo, R., Wang, Q. (2010): Effect of salt stress on phenolic compounds, glucosinolates, myrosinase and antioxidant activity in radish sprouts.- Food Chemistry 121(4):1014-1019.

[23] Zhu, J.K. (2001): Plant salt tolerance.- Trends in Plant Science 6(2):66-71. 